\title{
Response
}

\section{The Pricing of Inputs Sold to Competitors: Rejoinder and Epilogue}

\author{
William J. Baumol $\dagger$ \\ J. Gregory Sidakt†
}

In this piece, Baumol and Sidak respond to comments on their earlier essay on telecommunications that appeared in the Winter, 1994 issue of this Journal. They also comment on the reaction to their essay by the New Zealand Privy Council.

Introduction $\ldots \ldots \ldots \ldots \ldots \ldots \ldots \ldots \ldots \ldots \ldots$

I. Rejoinder ..................... 178

II. Epilogue: The Privy Council's Endorsement of the Efficient ComponentPricing Rule ..................... 179

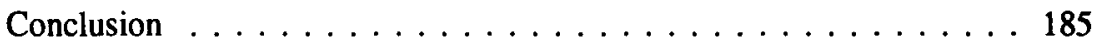

Introduction

This brief note has two purposes. First, we seek to avoid misunderstandings about the position we take after the appearance of the two extensive comments on our recent essay concerning the efficient component-pricing rule in this Journal. ${ }^{1}$ To summarize, we are in essential agreement with the comments of Professor Alfred Kahn and Dr. William Taylor, ${ }^{2}$ while, as is

†Director, C.V. Starr Center for Applied Economics, New York University; Professor Emeritus, Princeton University.

††Resident Scholar, American Enterprise Institute for Public Policy Research; Senior Lecturer, Yale School of Management.

1. William J. Baumol \& J. Gregory Sidak, The Pricing of Inputs Sold to Competitors, 11 YALE J. ON REG. 171 (1994).

2. Alfred E. Kahn \& William E. Taylor, The Pricing of Inputs Sold to Competitors: A Comment, 11 YALE J. ON REG. 225 (1994).

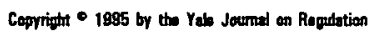


hardly surprising, we are totally unconvinced by Dr. William Tye's discussion. ${ }^{3}$

Our second, and larger, purpose is to report on the recent decision of the Judicial Committee of the Privy Council of the House of Lords that embraced our efficient component-pricing rule as a principle consistent with New Zealand antitrust law. The ruling emerged from a proceeding concerning the permissible price that the incumbent Telecom Corporation of New Zealand may charge the entrant Clear Communications for access to its local telephone network.

We conclude with some remarks about the likelihood that other courts and regulators, particularly those in the United States, will adopt the efficient component-pricing rule.

\section{Rejoinder}

The paper contributed by Professor Kahn and Dr. Taylor is clearly intended as an extension and clarification of our theme, and as such we can only welcome it. The authors do criticize us, with some justification, for having insufficiently qualified our exposition. In particular, they agree that the efficient component-pricing rule will do what we claim, and provide (to reuse the much overemployed phrase) a "level playing field" in an industry in which the incumbent holds a bottleneck input that must also be used by its competitor. Yet they note that, by itself, the rule, which requires a bottleneck input to be supplied at its incremental (marginal) cost, including its incremental (marginal) opportunity cost, if imposed without supplementary safeguards, requires the lessor of the bottleneck facilities to include in the rental payment whatever monopoly profits the bottleneck proprietor has been able to extract from other customers.

This reservation is entirely correct. In our recent book on local telephone regulation we have been most explicit about this concern, emphasizing the second economic efficiency requirement that, in addition to the efficient component-pricing rule, final product prices must be constrained by market forces or regulation so as to preclude monopoly profits. ${ }^{4}$ We have explicitly emphasized that the one rule, without the other, does not guarantee results that serve the public interest. If such points were inadequately emphasized in our Essay, we can only express our regrets.

Dr. Tye uses the forum provided by this Journal not really to discuss our essay, but to revisit old differences stemming from when he and one of us

3. William B. Tye, The Pricing of Inputs Sold to Competitors: A Response, 11 YALE J. ON REG. 203 (1994).

4. William J. Baumol \& J. Gregory Sidak, TOWaRd Competition in Local telephony 108, 140-41 (1994). 
previously appeared on opposite sides before various regulatory agencies. Thus, a good portion of Dr. Tye's paper takes Baumol to task for having argued elsewhere that voluntary negotiation was likely to result in acceptance of rental fees consistent with the efficient component-pricing rule. ${ }^{5}$ Since voluntary negotiations were not even mentioned in our essay and because they have no relevance to the subject matter at hand, these remarks by Dr. Tye are entirely beside the point-an ineffective attempt to settle irrelevant scores.

A second major topic of Dr. Tye's piece is his criticism that we simply propose a regulatory rule for the pricing of bottleneck inputs, and do not even consider a competitive solution as an alternative. ${ }^{6}$ That is true, so far as it goes. However, that is only because we have elsewhere already strongly expressed our preference for true competition, as against regulation, as the best means to ensure that business behavior promotes the public interest. We simply did not consider the competitive option to be part of the subject of our essay. Rather, that essay sought to answer the question, if faute de mieux, we happen in some circumstances to have no viable alternative to regulation, what does economic efficiency require the regulator to do about the prices of bottleneck inputs? It surely would have been nonsense for us to answer, "The regulator should turn to competition, even in circumstances where competition does not work."

But there is more to the matter. Dr. Tye, presumably without recognizing it, has often argued for promotion of what he considers to be competition by means of subsidies provided by the bottleneck proprietor to the competitor making use of the bottleneck facility. But this would just ensure the sort of pseudo-competition that is obtainable by tilting the playing field in favor of the bottleneck service buyer, and bringing business to that firm even when it is the less efficient provider. This result surely is but a caricature of true competition and hardly the way to promote economic efficiency.

The bottom line is this: it is easy to prove, as we have already done so in our essay and elsewhere, that the efficient component-pricing rule is a necessary condition for price to permit economic efficiency. There we leave the matter to rest.

II. Epilogue: The Privy Council's Endorsement of the Efficient ComponentPricing Rule

Several months after this Journal published its series of three essays on the efficient component-pricing rule, the highest court in the British Commonwealth embraced the rule, citing two of the essays. The Privy Council of the

5. Tye, supra note 3 , at 203.

6. Id. at 203. 
House of Lords held in Telecom Corporation of New Zealand Limited v. Clear Communications Limited that the efficient component-pricing rule is compatible with New Zealand antitrust principles governing the pricing of inputs sold to competitors. ${ }^{8}$

As we explained in our essay, ${ }^{9}$ New Zealand had precipitated by 1991 the first modern litigation over the pricing of interconnection among rival local telephone companies as a result of its policies promoting competition in telecommunications. New Zealand's lower court, known as the High Court, ruled that the incumbent local exchange carrier, Telecom, did not abuse a dominant position in the market in violation of New Zealand's antitrust statute, section 36 of the Commerce Act $^{10}$ when Telecom demanded that the entrant, Clear, pay an interconnection price derived from the efficient componentpricing rule. ${ }^{11}$ New Zealand's Court of Appeal, however, reversed on the grounds that it would violate section 36 for Telecom to include its foregone monopoly profit in the opportunity-cost component of the access charge paid by Clear under the efficient component-pricing rule. ${ }^{12}$ Telecom appealed that decision (and Clear cross-appealed other aspects of the decision not discussed here) to the Privy Council of the House of Lords in London.

On October 19, 1994, the Privy Council reversed in relevant part the decision of the Court of Appeal. Writing for their Lordships, Lord BrowneWilkinson considered the efficient component-pricing rule to have the following relevance to interpreting section 36's concept of "use of a dominant position":

As to what constitutes "use of a dominant position", although their Lordships agree with Gault J. [of the Court of Appeal] that ultimately the question depends upon the true effect of the statutory words used in section 36 and not on any economic model, the statutory words provide no explanation as to the distinction between conduct which does, and conduct which does not, constitute such use. Both the High Court and the Court of Appeal proceeded on the basis, with which their Lordships agree, that if the terms Telecom were seeking to

7. No. 21-94 (P.C. Oct. 19, 1994).

8. Id. at 23-24 (citing Baumol \& Sidak, supra note 1; Kahn \& Taylor, supra note 2).

9. Baumol \& Sidak, supra note 1 , at $190-95$.

10. Commerce Act, 1986, No. 5, \& 36, 1986 N.Z. Stat. 71, 95. Section 36(1) states: "No person who has a dominant position in a market shall use that position for the purpose of (a) Restricting the entry of any person into that or any other market; or (b) Preventing or deterring any person from engaging in competitive conduct in that or in any other market; or (c) Eliminating any person from that or any other market." Id.

11. Clear Communications, Ltd. v. Telecom Corp. of New Zealand, CP590/91 (H.C. Dec. 22, 1992), rev'd C.A. 25-93 (C.A. Dec. 17, 1993), rev'd No. $21-94$ (P.C., Oct. 19, 1994).

12. Clear Communications, Ltd. v. Telecom Corp. of New Zealand, C.A. 25-93 (C.A. Dec. 17, 1993), rev'd No. 21-94 (Oct. 19, 1994). 
extract were no higher than those which a hypothetical firm would seek in a perfectly contestable market, Telecom was not using its dominant position. In order to discover what such hypothetical terms might be it is inevitable that the parties and the court must have recourse to expert economic advice. The Baumol-Willig Rule is a closely reasoned economic model which seeks to show how the hypothetical firm would conduct itself. ${ }^{13}$

The Privy Council then considered whether the efficient component-pricing rule would violate section 36 by allowing Telecom to recover monopoly rents in the opportunity-cost component of the access price that it proposed to charge Clear.

Their Lordships emphasized that courts applying section 36 "are not acting as regulators" and that "section 36 is only one of the remedies provided by the Commerce Act for the purpose of combatting over-pricing due to monopolistic behavior." 14 Other sections of the Commerce Act, Lord Browne-Wilkinson observed, are available to perform this role:

Part IV [of the Commerce Act] deals separately with control of prices. Under section 53 the Governor-General, on the recommendation of the Minister, may declare that the prices for goods or services of any description supplied to or for the use of different persons are controlled. Under section 53(2)(a) a Minister cannot make such a recommendation unless he is satisfied the goods or services are supplied in a market "in which competition is limited or is likely to be lessened." Under section 70 the Commission may authorise a price to be charged for controlled services. Therefore section 36 is only part of an overall statutory machinery for dealing with trade practices which operate to the detriment of consumers. Another part of such machinery (Part IV) is specifically directed to the regulation of prices in markets which are not fully competitive. ${ }^{15}$

In our previous essay, we may have been taken to suggest that the Commerce Act provides no power to regulate prices. More precisely, we should have noted that such price regulation, while possible, was not in effect during the interconnection litigation between Telecom and Clear.

13. Slip op. at 21, Privy Council Appeal No. 21 of 1994 (Oct. 19, 1994, Judgment of the Londs of the Judicial Committee of the Privy Council). The "Baumol-Willig Rule" is another name given the efficient component-pricing rule because it was presented in the New Zealand litigation in the testimony of Professor Robert D. Willig and one of the present authors.

14. Id. at 22 .

15. Id. 
Perhaps as a consequence of our exiguous summary of New Zealand law on price regulation, counsel for Clear argued to the Privy Council that-as their Lordships restated the argument-our previous essay "amounted to a recantation by Professor Baumol ... . of the evidence [he] gave in this case. ${ }^{16}$ The controversy centered on two passages from the essay in which we discussed the possible persistence of monopoly rents in the efficient component price if no regulation existed to constrain monopoly pricing by Telecom. Quoting our Essay at length, Lord Browne-Wilkinson wrote:

Professor Baumol after referring to the judgment of the Court of Appeal in the present case said (at page 195):

"Given these circumstances, we must sympathize with the reasoning of the Court of Appeal. As we explain elsewhere, the efficient component-pricing rule plays its full beneficial role only when adopted as part of a set of complementary rules designed to promote consumer welfare. One such rule is that a monopolist should not be permitted to charge a price for a final product sold to consumers that is higher than the price that would attract an efficient entrant into the market-a price equal to the stand-alone cost of producing that final product. But, as Justice Cooke [of the High Court] noted, no such price ceiling exists under the current laws and regulations of New Zealand. It is therefore understandable that the Court of Appeal ordered Clear and Telecom to renew negotiations to set an access price that excluded any monopoly profit foregone by Telecom."

Later, after referring to the possible perpetuation of monopoly rents if opportunity costs are charged to an entrant, Professor Baumol said (at page 196):

"All this is true, but the villain is not the efficient component-pricing rule. The real problem is that the landlord has been permitted to charge monopoly prices for the final product in the first place. Had the ceiling upon finalproduct prices been based on stand-alone cost, which as we explain elsewhere it should be, the landlord could never have earned a monopoly profit in this regulatory

16. Id. at 23 (citing Baumol \& Sidak, supra note 1). 
scenario. The error, therefore, is the failure to impose the stand-alone cost ceiling on the final-product price, not the use of the efficient component-pricing rule. ${ }^{17}$

The Privy Council recognized that, contrary to the assertion of Clear's counsel, our discussion of the Court of Appeal's ruling was entirely consistent with Baumol's original testimony to the High Court. With respect to the preceding statements contained in our essay, Lord Browne-Wilkinson wrote:

In their Lordships' view, the statements by Professor Baumol are not a recantation by him of his evidence given in this case. Throughout, he has accepted that the Rule will initially perpetuate monopoly rents until either (a) they are competed out by Clear's competition in the contested area or (b) they are removed by regulatory action. He is not apparently aware that Part IV of the Commerce Act does in fact provide for a regulatory machinery which could be, but has not been, brought into operation. ${ }^{18}$

The Privy Council similarly saw no inconsistency between Professor Kahn's testimony to the High Court and his subsequent essay in this Journal with Dr. Taylor. ${ }^{19}$ Their Lordships found "nothing in these articles which alters the substance of the evidence considered by the High Court and the Court of Appeal."20 "The principal question remains, as it always was," wrote Lord Browne-Wilkinson, "whether the actual or potential presence of monopoly rents vitiates the validity of the Baumol-Willig model for the purposes of section 36. ${ }^{21}$

The Privy Council answered that question in the negative. Lord BrowneWilkinson wrote that "the risk of monopoly rents has no bearing upon the question whether the application of the Baumol-Willig Rule prevents competition in the contested area."22 "If both Telecom and Clear are charging their customers the same amount in the area in which they are not competitors," their Lordships reasoned, "this does not have any effect on their relative competitiveness in the area in which they compete." ${ }^{23}$ The Privy

17. Id. (citing Baumol \& Sidak, supra note 1, at 195, 196).

18. Id.

19. “Dr. Kahn also accepted throughout his evidence that, in the absence of regulatory control, his theory of competitive parity led to the possible continuance of monopoly rents. In the second article [on the efficient component-pricing rule] (at page 231-2) he persists in that view, although he too is under the misapprehension that no machinery exists in New Zealand to regulate the prices charged by Telecom to Clear." Id. at 24.
20. Id.
21. Id.
22. Id. at 27.
23. Id. 
Council stated that "the underlying object of section 36 will be achieved if the Rule is applied." 24

The Privy Council thus concluded that the Court of Appeal had erred when it "took the view that section 36 had the wider purpose, beyond producing fair competition, of eliminating monopoly profits currently obtained by the person in the dominant market position." 25 Part IV of the Commerce Act already authorized the government to impose explicit price regulation. It would misconstrue section 36, their Lordships concluded, "to extend its scope to produce a quasi-regulatory system which the Act expressly provides for, with all the necessary powers and safeguards, in another part of the Act."26 "The consequences of so doing could be unjust and would be impracticable. ${ }^{\text {27 }}$ Moreover, their Lordships seemed to consider it beyond the authority and competence of a court to undertake, in the absence of explicit legislation, the regulation of reasonable prices:

If, as their Lordships consider, on the true construction of the Commerce Act, section 36 does not operate to exclude Telecom from initially charging monopoly rents (if any) and the elimination of such monopoly rents is (otherwise than by competition) within the province of Part IV of the Act, it is irrelevant to the court's function to take into account Government policy. The Government can either adopt the policy of leaving Clear's competition to compete out Telecom's monopoly rents (if any) or activate the Part IV machinery which is available . . . . But what policy the Government adopts is no concern of the courts. ${ }^{28}$

Having so construed section 36 and the appropriate judicial function in resolving interconnection disputes, the Privy Council concluded that "the final position adopted by Telecom at trial based on the Baumol-Willig Rule did not breach section 36 since it did not involve the use by Telecom of its dominant position." 29

The Privy Council's decision also suggests how Telecom, despite its ostensible freedom from price regulation, may be subjected to what could be termed "virtual regulation." After noting that "at the end the of argument before their Lordships, the parties indicated that their negotiating positions are coming close together," Lord Browne-Wilkinson wrote that "Telecom accepts
24. Id.
25. Id.
26. Id. at 28 .
27. Id.
28. Id. at 29 .
29. Id. 
that it should not seek to recover any element of monopoly rents from Clear since, if necessary, such monopoly rents could be stripped out by the activation of Part IV of the Commerce Act. "30 Thus, the mere threat that the government may begin to regulate the price of the vertically integrated monopolist's final product may suffice to excise some or all of its monopoly rents from the opportunity-cost portion of the efficient component price. Stated differently, the incumbent's expected opportunity cost of providing interconnection to a competitor would exclude the monopoly rent over the final product.

Conclusion

Public utility commissions and courts in the United States are likely to pay close attention to the Privy Council's decision in Telecom v. Clear because of its thorough discussion of how the efficient component-pricing rule can be applied to local telecommunications markets. The Maryland Public Service Commission, for example, has been urged by Professor Kahn and Dr. Taylor, in testimony on behalf of Bell Atlantic, to adopt their variant of the efficient component-pricing rule, which they call the rule of "competitive parity," in a pending proceeding involving entry by a competitive access provider. ${ }^{31}$ For the foreseeable future, the central controversy addressed in the appellate phase of the New Zealand litigation-namely, the permissibility of allowing the incumbent firm to recover monopoly rents in the opportunity-cost component of its interconnection charge-will be a lesser concern in American regulatory proceedings than it was in New Zealand simply because virtually all state and federal regulatory jurisdictions in the United States currently regulate the prices monopolists can charge for their end products. Thus, the efficient componentpricing rule should be even more readily adopted in the United States than in countries with New Zealand's form of "light-handed" regulation.

The Privy Council's decision will also elicit interest from other network industries in which vertically integrated monopolists face the current or imminent obligation to sell inputs to competitors. The electric power industry is an obvious candidate for application of the efficient component-pricing rule. The Energy Policy Act of $1992^{32}$ amended section 211 of the Federal Power Act (FPA) ${ }^{33}$ to empower the Federal Energy Regulatory Commission to order vertically integrated electric utilities to deliver competitively generated power

30. Id.

31. MFS Intelenet of Md., Inc., Case No. 8584, Order No. 71155, 152 Pub. Util. Rep. 4th 102 (Md. Pub. Serv. Comm'n 1994).

32. Pub. L. No. 102-486, 106 Stat. 2776 (1992).

33. 16 U.S.C. $\$ 824$ et seq. (1985 \& Supp. 1994). 
over their transmission lines. ${ }^{34}$ Perhaps more important, the 1992 legislation amended section 212 of the FPA to require that rates charged for mandatory wholesale wheeling "shall promote the economically efficient transmission and generation of electricity. ${ }^{\text {"35 }}$ Those rates shall be high enough to "permit the recovery by such utility of all the costs incurred in connection with the transmission services and necessary associated services, including, but not limited to, an appropriate share, if any, of legitimate, verifiable and economic costs." 36 As our derivation of the efficient component-pricing shows, opportunity costs are indeed legitimate and verifiable and are economic costs borne by the vertically integrated monopolist when selling its inputs to competitors.

Finally, the Privy Council's discussion of the efficient component-pricing rule will provide guidance to American courts considering antitrust cases in which plaintiffs seek access to the essential facilities of vertically integrated monopolists that are not formally regulated by any government agency. The importance of such cases can be expected to grow as networks and information services of all sorts become more prominent features of the American economy.

34. Id. at \& 824j(a) (Supp. 1994).

35. Id. \& $824 \mathrm{k}$ (a) (Supp. 1994).

36. Id. (emphasis added). 